\title{
Factors Influencing the Adoption of E-Ticketing System in the Bus Transport Sector in Ghana
}

\author{
Paul Kwabena Tano Marfo', Emmanuel Quansah ${ }^{2}$ \\ ${ }^{1}$ Deutsche Welthungerhilfe e.V., Logistics Department, South Sudan Programme, Juba, South Sudan \\ ${ }^{2}$ Business School, Kwame Nkrumah University of Science and Technology, Kumasi, Ghana \\ Email: paulmarfo01@gmail.com
}

How to cite this paper: Marfo, P.K.T. and Quansah, E. (2020) Factors Influencing the Adoption of E-Ticketing System in the Bus Transport Sector in Ghana. Journal of Software Engineering and Applications, 13, 161-178.

https://doi.org/10.4236/jsea.2020.138011

Received: May 17, 2020

Accepted: August 7, 2020

Published: August 10, 2020

Copyright $\odot 2020$ by author(s) and Scientific Research Publishing Inc. This work is licensed under the Creative Commons Attribution International License (CC BY 4.0).

http://creativecommons.org/licenses/by/4.0/

\begin{abstract}
Electronic ticketing (E-ticketing), an innovative mode of issuing and delivering tickets, is becoming prevalent and is employed by many transport companies in Europe, America, Asia, and some parts of Africa to reduce the cost that goes with printing tickets. This study investigated E-ticketing adoption in the bus transport sector in the Kumasi Metropolis of Ghana. The study applied the Technology Acceptance Model (TAM), and the Structural Equation Modelling technique was used to analyse the factors affecting the intention to use the E-ticketing system. In that regard, the study was based on perceived usefulness, perceived ease of use, subjective norms, and demographic variables. Quantitative research approaches were used by distributing questionnaires to 392 passengers, employing the cluster and random sampling techniques. Findings from the study showed that perceived usefulness and subjective norm were the significant factors affecting passengers' intention to adopt the E-ticketing system. Besides, perceived ease of use and subjective norms were significant in predicting passengers' perceived usefulness of adopting E-ticketing system. The findings of this research will provide the government, industrial players, and the entire public a better understanding of the perceived factors that could enhance or serve as a barrier to passengers' adoption of the E-ticketing system. This can also lead to the development of effective E-ticketing marketing strategies.
\end{abstract}

\section{Keywords}

E-Ticketing System, Technology Acceptance Model,

Structural Equation Modelling,

Passengers 


\section{Introduction}

In recent times, consumers' ways of buying products and services have profoundly changed due to Information Technology (IT). Since the year 2000, many industries have employed the internet to market their products [1]. Thus, information technology is quickly altering the way people do business all over the world. The emergence of the electronic medium of commerce offers new opportunities to industries to adopt the Internet as their alternative marketing tools [2]. Information Technology has influenced various sectors of the global economy, including the transport sector. For example, the growing interest in e-commerce led to the introduction of electronic ticketing (E-ticketing) by airline industries [3].

The rapid growth of internet users globally provides a bright prospect for e-marketers in other areas of the transport sub-sector [4]. For many passengers, the additional time required to purchase individual tickets causes them to shy away from using public transportation [4], which seems to be possible in the context of Ghana. [5] identified that due to passengers' demand for convenient mobility solutions, there is a need for new, convenient, and user-friendly concepts of ticketing. For instance, the airline industry in Ghana has commenced employing E-ticketing for its reservation activities [6].

Factors influencing consumers' decision to adopt and appreciate a new service is very crucial and should be analysed before the service or product is rolled out [7]. Despite the advantages of the E-ticketing system, it has not been employed by bus transport operators in Ghana because there is a dearth of knowledge on its feasibility as an option to queuing at bus stations to purchase paper tickets. [8] stated that the Metro Mass Transit Limited (MMT) of Ghana was getting ready to roll out an electronic system of ticketing to aid in reducing cash handling and corruption. It is not known whether passengers would readily accept this system from MMT and other road transport operators.

Thus, this study examined the factors that could affect the adoption of the E-ticketing system by passengers. Concerning the factors, the Technology Acceptance Model with perceived usefulness, perceived ease of use, subjective norms, and demographic variables were used as factors that could influence passengers' intention to adopt E-ticketing system.

The paper is organised as follows; introduction, literature review and hypothesis, data analyses and results, discussion, conclusion and, reference list.

\section{Literature Review}

\section{Electronic Ticketing}

E-ticketing, the innovative mode of issuing and delivering tickets is becoming prevalent and is employed by many airline companies to reduce the costs that go with printing tickets. According to [9], E-ticketing system is a tool for the implementation of a pricing policy with the consideration of operational, commercial, and social objectives. The system came into existence in the United States of 
America in the 1980s, and it was primarily adopted by its domestic airline operator, United Airlines, in 1984 [4]. E-ticketing service is gaining popularity in the Asia Pacific region, particularly in the Philippines, Thailand, Hong Kong, and Malaysia [9] [10], stated that E-ticketing is a tool for the implementation of a pricing policy with the consideration of operational, commercial, and social objectives. E-ticketing system combines the issuance and delivery of tickets into a single operation [11]. The system stores information electronically and pursues a multi-service approach. In addition, the collected data provides accurate information on passenger flows, which can be used for planning purposes [12]. Therefore, there are no chances of the passenger losing these tickets or having them stolen. All the passenger needs to do is to carry photo identification or a ticket code. Thus, E-tickets substitutes the paper-based flight vouchers by an electronic ticket image.

\section{Technology Acceptance Model (TAM)}

There are many models in finding out the behavior pattern of consumers. Common examples include the Theory of Reason Action (TRA), Theory of Planned Behavior (TPB), and the Technology Acceptance Model (TAM). This study used the TAM to investigate the factors that influence the intentions of passengers to adopt the E-ticketing system. Many researchers have also used TAM to carry out studies on the intentions of customers regarding the use of a particular technology. The findings of some studies have shown that both perceived usefulness and perceived ease of use have a positive impact on the intentions of customers to use an E-ticketing system [13] [14] [15]. A review by [16] suggested that TAM is a valuable model to explain and recognize user behavior in the application of Information Systems. Also, the model has been proven to be a quality tool that produces reliable and satisfying results. In addition to perceived usefulness and perceived ease of use, subjective norms and demographic variables were introduced in the model to assess peoples' intention to adopt a system.

\section{Perceived Usefulness}

[17] identified perceived usefulness as a fundamental construct to determine the behavioural intention of users and mentioned that the functions that an application performs drive users to adopt the application. There is a high correlation between perceived usefulness and user acceptance of information technology. [17] defined perceived usefulness as the degree to which a person believes that using a particular system will enhance his or her job performance.

Perceived usefulness has consistently been shown to be a strong determinant of behavioural intention [18] [19]. According to [20], perceived usefulness a vital predictor of attitude for self-service technology adoption. Nonetheless, [15] indicated that perceived usefulness is not a significant factor that influences the intentions of people to use an E-ticketing system because some people are not concerned about the usefulness of E-ticketing system. In addition, [21] indicated that perceived usefulness has no direct relationship with the intention of people to purchase air tickets online. 


\section{Perceived Ease of Use}

The construct, perceived ease of use, as a factor influencing the user's intention of accepting online services system was recognized by [17]. It is defined as "the degree to which a person believes that using a particular system would be free of physical and mental efforts" [17] [22] also defined perceived ease of use as the standard to which the prospective consumer anticipates that online purchases would be free from external and internal effort. If identified as a stress-free system by users, then it will result in greater consumer intention to adopt the system [23]. Thus, a system that is perceived to be easier to use is more likely to be accepted by users. [20] also found that the ease of use of a system had a significant effect on behavioral intention, but not as strong as perceived usefulness. Nevertheless, [24] concluded that perceived ease of use has a significant negative effect on the intention to purchase or adopt a system.

\section{Subjective Norm}

The broad definition of a perceived or subjective norm is the perceived social pressure to perform or not to perform the behaviour in question [25]. [26] also defines it as one's perception of social pressure to perform or not to perform the behaviour under consideration. [18] concluded that subjective norm is a crucial determinant of behavioural intention. The social pressure experienced by a customer can influence the individual to adopt the system and not necessarily the usefulness or the ease of use. In likewise manner, [27] argued that the effect of subjective norms is more significant in the initial stages of system implementation. In a study by [28], subjective norm influenced customer's behavioural intentions to purchase. In applying TAM to understand students' behavioural intention to use E-learning technology, [29] noted that among all the constructs used in the proposed model, subjective norm had the second most important effect on both behavioural intention and attitude towards E-learning.

The effect of demographic variables on E-ticketing adoption

According to [30], a consumer purchase decision is influenced strongly by demographic, economic, social, situational, and technological factors. The nature of the economy, technology, and even the social setting can influence people's decisions. Four relevant demographic factors-age, gender, education, and internet experience-are found to significantly influence consumers' intention towards the adoption of new technology [31]. [32] also found that age, occupation, income, gender, and educational level have positive relationships with system adoption. In Malaysia, [4] reported that online ticket purchasers are the young, educated, professionals, and people in the higher income bracket.

Nevertheless, there is conflicting evidence about the influence of socio-demographic factors. The use of several internet services did not show uniform relationships with demographic factors in a study carried out by [33]. [34] also mentioned that age, gender, and income had a negative relationship with the adoption of mobile money transfer technology.

\section{Research Model (Figure 1)}




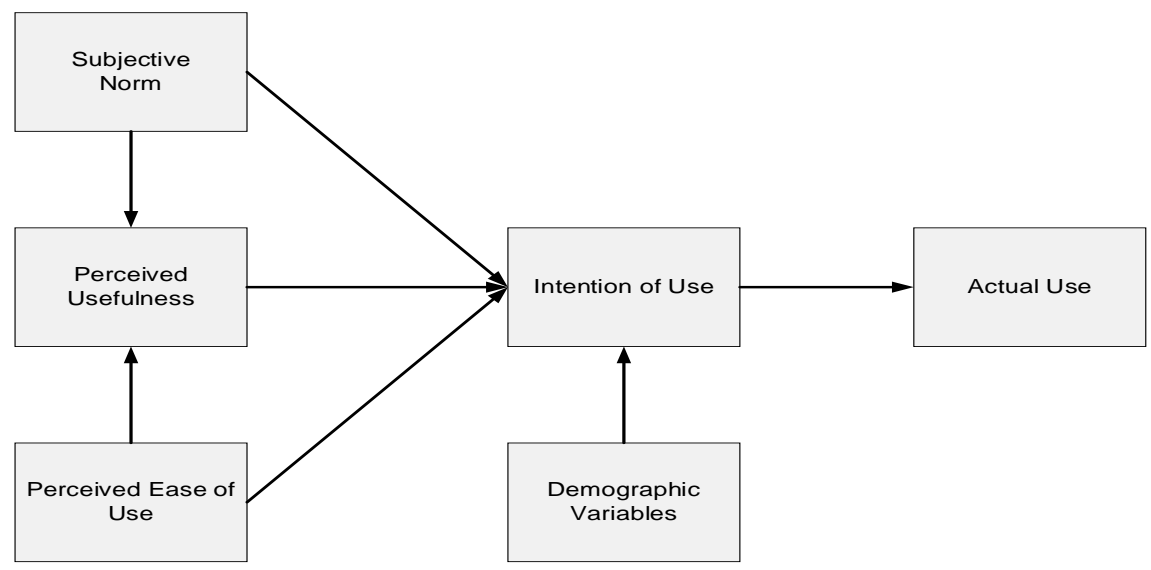

Figure 1. Schematic of a modified technology acceptance model (Davis, 1989).

\section{Hypothesis Development}

Four key determinants (perceived usefulness, perceived ease of use, demographic variables, and subjective norms) were selected as the independent variables of intentions to the use of E-ticketing technology. To test whether there is a relationship between the dependent and independent variables, the hypotheses included:

$\mathrm{H} 1$ : There is a positive relationship between perceived usefulness and intention to adopt the E-ticketing system in the bus transport sector in Ghana.

$\mathrm{H} 2$ : There is a positive relationship between perceived ease of use and intention towards the adoption of the E-ticketing system in the bus transport sector in Ghana.

H3: There is a positive relationship between subjective norm and intention towards the adoption of the E-ticketing system in the bus transport sector in Ghana.

H4: There is a positive relationship between demographic variables and intention towards the adoption of the E-ticketing system in the bus transport sector in Ghana.

H5: There is a positive relationship between subjective norm and perceived usefulness towards the adoption of the E-ticketing system in bus transportation.

H6: There is a positive relationship between perceived ease of use and perceived usefulness of the adoption of the E-ticketing system bus transportation.

\section{Research Methodology}

The study employed a descriptive and exploratory cross-sectional design based on the objectives of this study and the results of earlier studies. Based on the objective of this study, a quantitative approach was deemed to be very suitable. In addition, a cross-sectional survey was found to be appropriate because it allows many different variables to be compared.

The population target was all passengers within the Kumasi Metropolis. Kumasi Metropolis was selected as the study area because of its accessibility from all corners of the country. Besides, it was convenient to gather data at the Kumasi 
Metropolis because it serves as the hub of business activity in the region, and also serves as a nodal Metropolis with several transport routes. The passengers within the metropolis were divided among the seven distant transport companies, which were the Neoplan Branch-VIP of Ghana Private Road Transport Union (GPRTU), OA Travel and Tour, Metro Mass Transport, DKM Transport Ltd, State Transport Company (STC), GH Express, and the Asafo Branch of (GPRTU). These transport companies were selected because they are the main long-distance transport companies in the Kumasi metropolis. In choosing the samples, the study used a probability sampling technique to select respondents (passengers) from all the seven transport companies.

Data collection was done by a self-administrative survey with a questionnaire as the data collection tool. A questionnaire was used as a data-gathering tool because it can gather a large amount of data within a short period. The questionnaire consisted of five measures, namely demographic variables, perceived usefulness, perceived ease of use, subjective norm, and intention to use. The measures also consisted of an average of five questions with 26 sub-questions and a five Likert-scale ( $5=$ strongly agree, $1=$ strongly disagree). The questionnaire designed was pilot-tested to check for reliability and validity of the questions, the level of understanding of the respondents, and sensitivity of the questions. The restructured questionnaire after the pilot test was administered to 392 passengers, and there was a $94.8 \%$ response rate (372 completed questionnaires).

Statistical Package for the Social Sciences (SPSS) version 2015 was used for the data analysis. Because of the complexity of the study model and the objective of evaluating and understanding the various relationships among the dependent and independent variables, the Structural Equation Modelling was used for the analyses.

The consent of respondents was sought before being allowed to participate in the data collection. In addition, the privacy, confidentiality, and anonymity of all respondents who participated in this study were preserved.

\section{Data Analyses and Results}

The demographic characteristics of the respondents are summarized in Table 1. Of the 372 passengers who participated in the study, 66.9\% were males, and $33.1 \%$ were females. Also, 22.8\% of the respondents were below 20 years, and $38.4 \%, 21.2 \%$, and $12.1 \%$ were between 20 - 29 years, 30 - 39 years, and $40-49$ years, respectively. Only $5.4 \%$ of the respondents were above 49 years. Also, $50.8 \%$ of the respondents were economically employed, and $28.2 \%, 40.6 \%$, and $31.2 \%$ earned average monthly income/allowance of <GHS200, GHS200-1000, > GHS1000, respectively.

Most of the respondents (62.6\%) either hold $1^{\text {st }}$ Degree or $2^{\text {nd }}$ Degree. Based on the educational level, the competence of the respondents to complete the survey was considered adequate.

Except for the gender of the respondents, the distributions of the other demographic variables were well distributed, suggesting that adequate samples were 
Table 1. Demographic breakdown of respondents.

\begin{tabular}{|c|c|c|c|}
\hline & & Frequency & Percent \\
\hline \multirow{5}{*}{ Gender } & Female & 123 & $33.1 \%$ \\
\hline & Male & 249 & $66.9 \%$ \\
\hline & Total & 372 & \\
\hline & Below 20 & 85 & $22.8 \%$ \\
\hline & $20-29$ & 143 & $38.4 \%$ \\
\hline \multirow[t]{4}{*}{ Age (years) } & $30-39$ & 79 & $21.2 \%$ \\
\hline & $40-49$ & 45 & $12.1 \%$ \\
\hline & Above 50 & 20 & $5.4 \%$ \\
\hline & Total & 372 & \\
\hline \multirow{5}{*}{ Occupation } & Unemployed & 183 & $49.2 \%$ \\
\hline & Employed & 189 & $50.8 \%$ \\
\hline & Total & 372 & \\
\hline & Below 200 & 105 & $28.2 \%$ \\
\hline & $200-399$ & 52 & $14.0 \%$ \\
\hline \multirow{7}{*}{$\begin{array}{l}\text { Average monthly income } \\
\quad \text { (allowance) (GHS) }\end{array}$} & $400-599$ & 24 & $6.5 \%$ \\
\hline & $600-799$ & 26 & $7.0 \%$ \\
\hline & $800-999$ & 49 & $13.1 \%$ \\
\hline & 1000 or above & 116 & $31.2 \%$ \\
\hline & Total & 372 & \\
\hline & WASSCE/O'Level/similar & 113 & $30.4 \%$ \\
\hline & Diploma/HND & 25 & $6.7 \%$ \\
\hline \multirow[t]{4}{*}{ Education level } & 1st Degree & 164 & $44.1 \%$ \\
\hline & 2nd Degree & 69 & $18.5 \%$ \\
\hline & $\mathrm{PhD}$ & 1 & $0.3 \%$ \\
\hline & Total & 372 & \\
\hline
\end{tabular}

drawn from every sub-group for the study. In the subsequent sections of the chapter, the potential effects of these demographic variables on the proposed framework of the study were controlled before estimating the proposed relationships between the constructs.

The study was based on three broad areas: measurement model analysis, structural model analysis, and evaluation of hypotheses.

\section{Measurement model analysis}

It has been reported that perceived usefulness (PU) of technology is a driving factor for the intention to use or not to use the technology [20]. The results of $\mathrm{PU}$, as shown in Table 2, indicate that an average proportion of the respondent agreed that the extent of benefits to be derived from E-ticketing in the road transport industry would be high when adopted. The composite mean score of PU 
Table 2. Variables.

\begin{tabular}{|c|c|c|c|}
\hline & \multicolumn{3}{|c|}{ Test value $=4.00$} \\
\hline & Mean & Std. Dev. & t-values \\
\hline PU 1 & 5.79 & 1.108 & $31.158^{*}$ \\
\hline PU 2 & 6.19 & 0.884 & $47.847^{\star}$ \\
\hline PU 3 & 6.12 & 0.949 & $43.003^{*}$ \\
\hline PU 4 & 5.97 & 1.124 & $33.813^{*}$ \\
\hline PU 5 & 6.12 & 1.063 & $38.468^{*}$ \\
\hline PU 6 & 6.17 & 0.896 & $46.654^{*}$ \\
\hline Perceived usefulness Overall composite score & 6.06 & 0.733 & $54.218^{*}$ \\
\hline PEU & 5.18 & 1.466 & $15.530^{*}$ \\
\hline PEU & 5.22 & 1.413 & $16.585^{*}$ \\
\hline PEU & 6.01 & 1.091 & $35.436^{*}$ \\
\hline PEU & 5.92 & 1.275 & $29.084^{*}$ \\
\hline PEU & 5.98 & 1.244 & $30.683^{*}$ \\
\hline Perceived ease of use Overall composite score & 5.66 & 0.946 & $33.853^{*}$ \\
\hline SN 1 & 5.06 & 1.681 & $12.150^{*}$ \\
\hline SN 2 & 5.35 & 1.610 & $16.129^{*}$ \\
\hline SN 3 & 5.45 & 1.544 & $18.104^{*}$ \\
\hline SN 4 & 5.39 & 1.604 & $16.712^{*}$ \\
\hline SN 5 & 5.61 & 1.496 & $20.795^{*}$ \\
\hline Subjective norm Overall composite score & 5.37 & 1.248 & $21.198^{\star}$ \\
\hline ITU & 6.01 & 1.056 & $36.615^{*}$ \\
\hline ITU & 5.98 & 1.039 & $36.665^{\star}$ \\
\hline ITU & 6.12 & 0.946 & $43.132^{*}$ \\
\hline ITU & 6.19 & 0.992 & $42.575^{\star}$ \\
\hline ITU & 6.08 & 1.056 & $37.896^{*}$ \\
\hline Intention to Use Overall composite score & 6.07 & 0.7201 & $55.509^{*}$ \\
\hline
\end{tabular}

$\mathrm{N}=372 ; \mathrm{df}=371$; significant at $1 \%$ (two-tailed test).

was $6.06 \pm 0.733$, and it was significantly greater than 4.00 , the threshold in which respondents are unable to determine whether the system would be useful or not.

Authors, such as [17] [20] [21], report that people's tendency to use systems would be influenced by the degree to which they believe that using the system would be free of physical and mental efforts, termed as "perceived ease of use" (PEU). As shown in Table 2, an average proportion of the respondents agreed that the PEU construct is relevant in determining whether road transport passengers would patronize E-ticketing or not. The average PEU score was significantly above 4.00 , implying that E-ticketing system was generally perceived by 
the passengers as easy to use.

As theory puts it, one's behavioural intentions to act in a given situation is often influenced by social pressure [25] [26].

The overall mean score of Subjective Norm (SN) was also found to be higher than 4.00 , and it was significant at $1 \%$; $\mathrm{t}(371)=21.198$.

In sum, these results on Intention to Use (ITU) $(1 \%$; $(371)=55.509)$ point out that bus transport passengers are willing and ready for E-ticketing services. This result is congruent with the study of [14], who observed that users willingly use a system when it has useful functionality.

Cronbach alpha was used to assess the internal consistency among the measures of each construct. The results obtained are reported in Table 3. Among the four constructs, the least alpha value obtained was 0.749 (for intention to use), which is above the recommended threshold of 0.70 [35]. Thus, it implies that each scale had strong internal consistency among the measures employed [36].

\section{Exploratory Factor Analysis (EFA)}

Although all items employed in this study were specified as measuring their respective constructs, it became necessary to rely on exploratory factor analysis to help identify and eliminate cross-load of some of the measures on other factors. Also, the exploratory factor analysis will avoid the case where some of the constructs were insufficiently explained by a given factor (i.e., the factor doesn't load well on its specified construct).

The factor extraction method employed was Principal Factor Axis. The rotation method was Direct Oblimin with Kaiser Normalization. Also, the system was set to only extract factors with Eigenvalues greater than 1.00 and to suppress loadings less than 0.50. In order to assess the sample adequacy for EFA, the Kaiser-Meyer-Olkin (KMO) measure was used. The KMO measure obtained (0.876) exceeded the recommended value of 0.60 which implies satisfactory sample adequacy for the analysis [36] and Bartlett's Test of Sphericity reached a statistical significance level of $1 \%$, given $\chi^{2}(210)=3097.517, \mathrm{p}<0.001$; supporting the factorability of the correlation matrix [37].

Four of the factor solutions explained a total of $47.4 \%$ of the variance, with components $1,2,3$, and 4 accounting for $29.6 \%, 9.0 \%, 4.8 \%$, and $4.0 \%$ of the variation, respectively. Out of the 21 items that were subjected to the EFA, 14 were retained and further used for confirmatory factor analysis (CFA); 3, 5, 2, and 4 items were retained on component 1 (ITU), 2 (SN), 3 (PEU), and 4 (PU), respectively (see Table 4 ).

Table 3. Scale reliability.

\begin{tabular}{lcc}
\hline \multicolumn{1}{c}{ Constructs } & Number of items & Cronbach alpha \\
\hline 1) Perceived usefulness & 6 & 0.821 \\
2) Perceived ease of use & 5 & 0.775 \\
3) Subjective norm & 5 & 0.845 \\
4) Intention to use & 5 & 0.749 \\
\hline
\end{tabular}


Table 4. Pattern matrix.

\begin{tabular}{|c|c|c|c|c|}
\hline & \multicolumn{4}{|c|}{ Factor } \\
\hline & 1 & 2 & 3 & 4 \\
\hline PU1 & & & & -0.738 \\
\hline PU2 & & & & -0.820 \\
\hline PU3 & & & & -0.811 \\
\hline PU4 & & & & -0.554 \\
\hline \multicolumn{5}{|l|}{ PU5 } \\
\hline \multicolumn{5}{|l|}{ PU6 } \\
\hline PEU1 & & & -0.850 & \\
\hline PEU2 & & & -0.607 & \\
\hline \multicolumn{5}{|l|}{ PEU3 } \\
\hline \multicolumn{5}{|l|}{ PEU4 } \\
\hline \multicolumn{5}{|l|}{ PEU5 } \\
\hline SN1 & & -0.693 & & \\
\hline SN2 & & -0.773 & & \\
\hline SN3 & & -0.915 & & \\
\hline SN4 & & -0.636 & & \\
\hline SN5 & & -0.522 & & \\
\hline ITU1 & 0.720 & & & \\
\hline ITU2 & 0.749 & & & \\
\hline \multicolumn{5}{|l|}{ ITU3 } \\
\hline ITU4 & 0.575 & & & \\
\hline ITU5 & & & & \\
\hline
\end{tabular}

Extraction Method: Principal Axis Factoring.

\section{Confirmatory factor analysis (CFA)}

Given the retained items after the EFA, a confirmatory factor analysis (CFA) was used further to refine the items and to help validate the scales. This analysis was performed using Linear Structural Relations (Lisrel 8.8). Relying on the Maximum likelihood estimation method, several purifications of the measures were conducted. The final model provided a good fit to the data: $\chi^{2}(\mathrm{df})=$ 47.53(21); RMSEA = 0.058; NNFI = 0.963; CFI $=0.979$; $\mathrm{SRMR}=0.036$.

$\left[\chi^{2} \rightarrow\right.$ Chi-square, $d f \rightarrow$ degree of freedom, RMSEA $\rightarrow$ root mean square error of approximation, $N N F I \rightarrow$ nonnormed fit index, $C F I \rightarrow$ comparative fit index, $S R M R \rightarrow$ standardized root mean square residual].

The final items retained for estimating the structural model with the respective loadings, errors, $\mathrm{t}$-values, and $\mathrm{R}^{2} \mathrm{~s}$ are shown in Table 5 . All factor loadings were significant at $1 \%$. The positive and significant loadings confirm the convergent validity of the measures retained [37]. 
Table 5. Measurement model results.

\begin{tabular}{cccccc}
\hline Constructs and measures & & Loadings & Errors & T-value & $\mathrm{R}^{2}$ \\
\hline Perceived usefulness $(P U)$ & & & & & \\
& PU1 & 0.784 & 0.386 & Fixed & 0.614 \\
& PU3 & 0.788 & 0.379 & 13.99 & 0.624 \\
& PU4 & 0.772 & 0.404 & 14.81 & 0.596 \\
Perceived ease of use $($ PEU $)$ & & & & & \\
& PEU1 & 0.893 & 0.203 & Fixed & 0.797 \\
Subjective norm $($ SN $)$ & PEU2 & 0.766 & 0.413 & 10.01 & 0.587 \\
& & & & & \\
& SN1 & 0.64 & 0.465 & Fixed & 0.409 \\
& SN2 & 0.732 & 0.481 & 7.26 & 0.535 \\
& & & & & \\
\hline Intention to use $($ ITU $)$ & ITU1 & 0.721 & 0.481 & Fixed & 0.519 \\
& ITU4 & 0.654 & 0.572 & 7.34 & 0.428 \\
\hline
\end{tabular}

Loadings significant at $1 \%$.

Also, the correlation between the constructs, $\mathrm{R}^{2} \mathrm{~s}$, construct reliability (CR), and the average variance extracted (AVE) for the constructs are shown in Table 6. The CRs and AVEs were satisfactory. Also, all the AVEs were larger than the highest $\mathrm{R}^{2}$ between the constructs, signifying satisfactory discriminant validity [37].

\section{Assessment of Method Bias}

The common method bias was assessed in this study to ensure that the data collected were of good quality and appropriate for model estimation. A one-factor model was developed in Lisrel by allowing all retained items to load on one latent variable. This analysis yielded the following results: $\chi^{2}(\mathrm{df})=440.37(27)$; $\mathrm{RMSEA}=0.203$; NFI $=0.631$; CFI $=0.723$; $\mathrm{SRMR}=0.126$. These results generally indicate poor fit to the data, implying that the items do not share one underlying concept, and thus the common method bias does not adequately describe the data or pose a threat to the quality of data collected for the study.

\section{Structural Model Analysis}

For parsimonious reasons, a multiple-indicator multiple-cause (MIMIC) models were used in the model estimations [35]. Also, the demographic variablesgender and employment status-were treated as dummy variables and coded as follows: Male $=1$, Female $=0$; Employed $=1$, Unemployed $=0$. While age, education level, and income levels were treated as ordinal variables and assigned discrete values. Following the recommended procedures employed by previous researchers [20], the proposed model in this study was compared with seven other competing models. 
Table 6. Correlation among constructs and CRs and AVEs.

\begin{tabular}{lccccc}
\hline & Variables & $\mathbf{1}$ & $\mathbf{2}$ & $\mathbf{3}$ & $\mathbf{4}$ \\
\hline 1$)$ & Perceived usefulness (PU) & & 0.158 & 0.112 & $0.319^{*}$ \\
$2)$ & Perceived ease of use (PEU) & 0.397 & & 0.293 & 0.065 \\
$3)$ & Subjective norm (SN) & 0.334 & 0.541 & & 0.213 \\
$4)$ & Intention to use (ITU) & 0.565 & 0.255 & 0.462 & \\
& Mean & 5.95 & 5.20 & 5.37 & 6.10 \\
& Standard deviation & 0.881 & 1.301 & 1.377 & 0.858 \\
& Composite reliability (CR) & 0.825 & 0.817 & 0.666 & 0.642 \\
& Average variance extracted (AVE) & $\mathbf{0 . 6 1 0}$ & $\mathbf{0 . 6 9 2}$ & $\mathbf{0 . 5 0 0}$ & $\mathbf{0 . 4 7 4}$ \\
\hline
\end{tabular}

Note: 1) Values above the diagonal represent $\mathrm{R}^{2}$ between constructs; 2) Highest $\mathrm{R}^{2}$ between construct $<$ least AVE among constructs; indicating discriminant validity.

The various models tested, with their respective Chi-square and degree of freedom values, changes in Chi-square and degree of freedom, and other goodness of fit indices are shown in Table 7. Based on the results provided in Table 7 , it can be seen that all the models run after the baseline model improved the model fit to data. However, it was noted that Model 4 and Model 7 yielded better results (in terms of more satisfactory goodness of fit indices) than the proposed model derived in this study (Model 6). This was because some of the paths of the proposed model were non-significant; hence, adding them makes the model fit the data poorly. The standardized beta values and the t-values of Model 6 are shown in Figure 1.

\section{Model specification in LISREL: SIMPLIS syntax}

Baseline model

$$
\begin{gathered}
\mathrm{ITU}=\mathrm{GEND}+\mathrm{OCCP}+\mathrm{AGE}+\mathrm{EDUC}+0 \times \mathrm{PU}+0 \times \mathrm{PEU}+0 \times \mathrm{SN} \\
\mathrm{PU}=0 \times \mathrm{PEU}+0 \times \mathrm{SN}
\end{gathered}
$$

Model 1

$$
\begin{gathered}
\mathrm{ITU}=\mathrm{GEND}+\mathrm{OCCP}+\mathrm{AGE}+\mathrm{EDUC}+\mathrm{PU}+0 \times \mathrm{PEU}+0 \times \mathrm{SN} \\
\mathrm{PU}=0 \times \mathrm{PEU}+0 \times \mathrm{SN}
\end{gathered}
$$

Model 2

$$
\begin{gathered}
\mathrm{ITU}=\mathrm{GEND}+\mathrm{OCCP}+\mathrm{AGE}+\mathrm{EDUC}+\mathrm{PU}+\mathrm{PEU}+\mathrm{SN} \\
\mathrm{PU}=0 \times \mathrm{PEU}+0 \times \mathrm{SN}
\end{gathered}
$$

Model 3

$$
\begin{gathered}
\mathrm{ITU}=\mathrm{GEND}+\mathrm{OCCP}+\mathrm{AGE}+\mathrm{EDUC}+0 \times \mathrm{PU}+\mathrm{PEU}+\mathrm{SN} \\
\mathrm{PU}=\mathrm{PEU}+\mathrm{SN}
\end{gathered}
$$

Model 4

$$
\begin{gathered}
\mathrm{ITU}=\mathrm{GEND}+\mathrm{OCCP}+\mathrm{AGE}+\mathrm{EDUC}+\mathrm{PU}+0 \times \mathrm{PEU}+\mathrm{SN} \\
\mathrm{PU}=\mathrm{PEU}+\mathrm{SN}
\end{gathered}
$$


Table 7. Structural model: alternative model comparisons.

\begin{tabular}{cccccccccc}
\hline Model & $\chi^{2}$ & df & $\Delta \chi^{2}$ & $\Delta$ df & $\chi^{2} /$ df & RMSEA & NNFI & CFI & SRMR \\
\hline Baseline model (BM) & 192.79 & 31 & - & - & 6.22 & 0.119 & 0.823 & 0.900 & 0.134 \\
Model 1 & 116.83 & 30 & $75.96^{* *}$ & 1 & 3.89 & 0.088 & 0.893 & 0.942 & 0.100 \\
Model 2 & 101.20 & 28 & $91.59^{* *}$ & 3 & 3.61 & 0.084 & 0.901 & 0.942 & 0.089 \\
Model 3 & 104.28 & 27 & $88.51^{* *}$ & 4 & 3.86 & 0.088 & 0.893 & 0.947 & 0.083 \\
Model 4 & 62.22 & 27 & $130.57^{* *}$ & 4 & 2.30 & 0.059 & 0.953 & 0.977 & 0.044 \\
Model 5 & 74.19 & 27 & $118.60^{* *}$ & 4 & 2.75 & 0.069 & 0.939 & 0.970 & 0.048 \\
Model 6 & 62.14 & 26 & $130.65^{* *}$ & 5 & 2.39 & 0.061 & 0.950 & 0.976 & 0.044 \\
Model 7 & 65.61 & $\mathbf{3 0}$ & & & 2.19 & $\mathbf{0 . 0 5 7}$ & $\mathbf{0 . 9 5 7}$ & $\mathbf{0 . 9 7 7}$ & $\mathbf{0}$ \\
\hline
\end{tabular}

NNFI: Bentler non-normed fit index; CF: comparative fit index; RMSE: root mean square error of approximation; SRMR: standardized root mean square residual. ${ }^{* *} \mathrm{p}<0.001 ; \Delta=$ baseline model (BM) value minus non-baseline model value.

Model 5

$$
\begin{gathered}
\mathrm{Itu}=\mathrm{GEND}+\mathrm{OCCP}+\mathrm{AGE}+\mathrm{EDUC}+\mathrm{Pu}+\mathrm{PEU}+0 \times \mathrm{SN} \\
\mathrm{Pu}=\mathrm{PEU}+\mathrm{SN}
\end{gathered}
$$

Model 6

$$
\begin{gathered}
\mathrm{Itu}=\mathrm{GEND}+\mathrm{OCCP}+\mathrm{AGE}+\mathrm{EDUC}+\mathrm{Pu}+\mathrm{PEU}+\mathrm{SN} \\
\mathrm{Pu}=\mathrm{PEU}+\mathrm{SN}
\end{gathered}
$$

Model 7

$$
\begin{gathered}
\mathrm{Itu}=0 \times \mathrm{GEND}+0 \times \mathrm{OCCP}+0 \times \mathrm{AGE}+0 \times \mathrm{EDUC}+\mathrm{Pu}+\mathrm{PEU}+\mathrm{SN} \\
\mathrm{Pu}=\mathrm{PEU}+\mathrm{SN}
\end{gathered}
$$

\section{Evaluation of hypotheses and findings}

Given the test results, and regarding the relationships specified by the proposed model, the following analysis and insights can be derived:

1) Perceived usefulness serves as both full and partial mediating variable for perceived ease of use and subjective norm, respectively, given that:

2) The perceived ease of use does not significantly affect the intention to use, but it works through perceived usefulness, then to intention to use a given technology, and

3) There exist both a direct effect and indirect effect of subjective norm on the intention to use.

The proposed model of this study was able to account for $13.6 \%$ and $38.2 \%$ variations in perceived usefulness and intention to use E-ticketing. In this study, four out of the five propositions were statistically supported by the empirical data, as shown in Table 8. 
Table 8. Results for hypothesis.

\begin{tabular}{|c|c|c|c|}
\hline & Hypothesis & Results & Decision \\
\hline H1: & $\begin{array}{l}\text { There is a positive relationship between perceived } \\
\text { usefulness and intention to adopt e-ticketing }\end{array}$ & $\begin{aligned} & \beta=0.51 \\
\mathrm{t}= & 6.60 ; \mathrm{p}<0.01\end{aligned}$ & Supported \\
\hline $\mathrm{H} 2$ : & $\begin{array}{l}\text { There is a positive relationship between perceived } \\
\text { ease of use and intention to adopt e-ticketing }\end{array}$ & $\begin{array}{c}\beta=-0.01 \\
\mathrm{t}=-0.15 ; \mathrm{p}>0.05\end{array}$ & Not supported \\
\hline H3: & $\begin{array}{l}\text { There is a positive relationship between subjective } \\
\text { norm and intention to adopt e-ticketing }\end{array}$ & $\begin{array}{c}\beta=0.22 \\
\mathrm{t}=3.29, \mathrm{p}<0.01\end{array}$ & Supported \\
\hline $\mathrm{H} 4:$ & $\begin{array}{l}\text { There is a positive relationship between subjective } \\
\text { norm and perceived usefulness of e-ticketing }\end{array}$ & $\begin{aligned} & \beta=0.14 \\
\mathrm{t}= & 2.28, \mathrm{p}<0.05\end{aligned}$ & Supported \\
\hline H5: & $\begin{array}{l}\text { There is a positive relationship between perceived } \\
\text { ease of use and perceived usefulness of e-ticketing }\end{array}$ & $\begin{aligned} & \beta=0.29 \\
\mathrm{t}= & 4.85, \mathrm{p}<0.01\end{aligned}$ & Supported \\
\hline
\end{tabular}

\section{Discussion}

Over the years, many researchers have used TAM model to carry out studies on the intention to use technology and have proven that both perceived usefulness and perceived ease of use have a positive impact on intention to use E-ticketing system [13] [14] [15]. Based on the literature reviewed, three key constructs were identified and considered as important in influencing people's intention to adopt a given technology or system. These constructs were: 1) perceived usefulness of the technology, 2) perceived ease of use and 3) subjective norm.

The results for perceived usefulness $(\beta=0.51 ; \mathrm{t}=6.60, \mathrm{p}<0.01)$ confirmed the theory and findings from other empirical studies [17] [18] [19]. Specifically, [20] reported that perceived usefulness is a vital predictor of attitude for the adoption of self-service technologies. This finding implies that when consumers perceive that using a particular technology or system would be more beneficial, they are more likely to develop a positive adoption attitude towards the technology or system. In the case of this study, it was found that bus transport passengers who perceive E-ticketing to be more useful were more likely to use the system should it be adopted in the industry.

Perceived ease of use was not a good predictor for the tendency to use the E-ticketing system in this study $(\beta=-0.01 ; \mathrm{t}=-0.15, \mathrm{p}>0.05)$, which contradicts the theory of other empirical findings [20] [21]. The model predicted that passengers perceive the E-ticketing system to be less user-friendly and therefore using the system will not be free of physical and mental efforts. This finding is in line with the findings of other authors, such as [24] who reported that perceived ease of use has a negative significant effect on the intention to purchase.

In addition, social pressures from family, peers, and one's status in life were significant factors that will influence the tendency of people to adopt the E-ticketing system. This agrees with earlier empirical findings. For example, [27] indicated that the effect of a subjective norm is very significant in the initial stages of system implementation. Also, the results of a study by [29] on E-learning technology, showed that among all construct used, subjective norm had the second most 
important effect on both behavioural intention and attitude toward the adoption of the system.

The relationship between subjective norm and perceived usefulness in this study was significant $(\beta=0.14 ; \mathrm{t}=2.28, \mathrm{p}<0.05)$. This implies that when a subjective norm is more prevalent (e.g., when most members of a given social group are using a particular technology or systems), people are more likely to find the technology more useful, although left to them alone, they would not have seen the importance of the technology. Based on this finding, it can be said that subjective norm is an important determinant of one's perception of the usefulness of E-ticketing.

The influence of perceived ease of use on perceived usefulness was significant ( $\beta=0.29 ; \mathrm{t}=4.85, \mathrm{p}<0.01)$, implying that when people perceive a given system to be more useful, perceived ease of use would be higher, i.e., they will be more likely to learn how to use the system. It can be, however, ascertained that individuals who perceive a given technology as easy to use are more likely to consider it as beneficial to them. Hence, this confirms the report by [20] who found that the effect of perceived ease of use a system on the perceived usefulness is stronger than the intention to use the system.

\section{Conclusions}

The result showed that perceived usefulness and subjective norms have a positive influence on the intention towards the purchase of E-ticket should it be adopted. However, the demographic variables and perceived ease of use were not a strong predictor of the intention to use the system. Although perceived ease of use could not predict the intention to use, subjective norm and perceived ease of use could easily influence the perceived usefulness of the system if it is adopted. This indicates the effect of subjective norm and perceived usefulness on potential users with no prior experience. The results also indicate that marketing tools, such as advertisements in media, could play an important role in informing the intention of the potential users of the system. It can enhance the favourability of consumers towards the purchasing of E-tickets should it be adopted. Based on the results of this study, demography and perceived ease of use are factors that do not influence the intention towards the adoption of E-ticketing system should it be rolled out in the Ghana bus transport sector. However, perceived ease of use could influence perceived usefulness.

Perceived usefulness and intention to use a particular technology are not only dependent on the subjective norm and the perceived ease of use, but also other numerous factors. Thus, further studies that account for the multiple factors are suggested. This is because the other factors could also drive passengers' perceptions of the usefulness of the E-ticketing system in the road transport industry in Ghana, as well as the tendency that they will use the system.

\section{Conflicts of Interest}

The authors declare no conflicts of interest regarding the publication of this paper. 


\section{References}

[1] Dholakia, R. R. and Uusitalo, O. (2002) Switching to Electronic Stores: Consumer Characteristics and the Perception of Shopping Benefits. International Journal of Retail and Distribution Management, 30, 459-469. https://doi.org/10.1108/09590550210445335

[2] Narwal, M. and Sachdeva, G. (2013) Impact of Information Technology on Consumer Purchase Behaviour. Researchers World, 4, 41.

[3] Travel and Tourism (2005) E-Ticketing at Home Page. http://www.travelandtourism.com/

[4] Sulaiman, A., Ng, J. and Mohezar, S. (2008) E-Ticketing as a New Way of Buying Tickets: Malaysian Perceptions. Journal of Social Science, 17, 149-157. https://doi.org/10.1080/09718923.2008.11892644

[5] Siemens (2012) Integrated Mobility with E-Ticketing. https://documents.pub/document/integrated-mobility-with-eticketing-mobility-wit h-eticketing-as-a-system-supplier.html

[6] ZenithBank Ghana (2015) Enjoy the Convenience of Internet Banking. https://www.zenithbank.com.gh/media-centre/news/zenith-cements-leadership-incashless-banking-space/

[7] Dehbashi, S. and Nahavandi, N. (2009) Effect of Perceived Risk, Perceived Usefulness, Trust and IT-Related Knowledge on Adoption of E-Ticketing in Iran. World Applied Science Journal, 6, 86-96.

[8] Ghanatrade (2014) Metro Mass Transit to Introduce Electronic Ticketing. www.ghanatrade.gov.gh/Latest-News/metro-mass-transit-to-intoduce-electronic-tic keting.html

[9] Mezghani, M. (2008) Report on Study on E-Ticketing in Public Transport European Metropolitan Transport Authority.

[10] SITA (2005) 7th Airline IT Trends Survey 2005: The Future of 21st Century Travel. http://www.sita.aero/NR/rdonlyres/08255EF6-383B-481F-9C82-560AEF7ACCEA/0 /Airline IT Trends 2005 report.pdf

[11] Ng-Kruelle, G., Swatman, P.A. and Kruelle, O. (2006) E-Ticketing Strategy and Implementation in Open Access System: The Case of Deutshe Bahn. No. 3, 86-113. https://www.researchgate.net/publication/228883725 e-Ticketing Strategy and Im plementation in an Open Access System The case of Deutsche Bahn

[12] Puhe, M., Edelmann, M. and Reichenbach, M. (2014) Integrated Urban E-Ticketing for Public Transport and Touristic Sites. Science and Technology Options Assessment Options Brief No 2014-02.

[13] Taylor, S. and Todd, P.A. (1995) Understanding Information Technology Usage: A Test of Competing Model. Information Systems Research, 6, 85-188.

https://doi.org/10.1287/isre.6.2.144

[14] Lee, Y.H., Kozar, A.K. and Larsen, K.R.T. (2003) The Technology Acceptance Model: Past, Present, and Future. Communications of the Association for Information Systems, 12, 752-780. https://doi.org/10.17705/1CAIS.01250

[15] Wan, G.H. and Che, P. (2004) Chinese Air Travelers' Acceptance towards Electronic Ticketing. 2004 IEEE International Engineering Management Conference, Singapore, 18-21 October 2004, 269-275. https://doi.org/10.1109/IEMC.2004.1407118

[16] Legris, P., Ingman, I. and Collerette, P. (2003) Why Do People Use Information Technology? A Critical Review of the Technology Acceptance Model. Information \& Management, 40, 191-204. https://doi.org/10.1016/S0378-7206(01)00143-4 
[17] Davis, F.D. (1989) Perceived Usefulness, Perceived Ease of Use, and User Acceptance of Information Technology. MIS Quarterly, 13, 319-340. https://doi.org/10.2307/249008

[18] Davis, F.D. (1993) User Acceptance of Information Technology: System Characteristics, User Perceptions and Behavioral Impacts. International Journal of Man-Machine Studies, 38, 475-487. https://doi.org/10.1006/imms.1993.1022

[19] Venkatesh, V. and Davis, F.D. (2000) A Theoretical Extension of the Technology Acceptance Model: Four Longitudinal Field Studies. Management Science, 46, 186-204. https://doi.org/10.1287/mnsc.46.2.186.11926

[20] Lu, Y., Zhou, L., Bruton, G. and Li, W. (2010) Capabilities as a Mediator Linking Resources and the International Performance of Entrepreneurial Firms in an Emerging Economy. Journal of International Business Studies, 41, 419-436. https://doi.org/10.1057/jibs.2009.73

[21] Bigné, E., Sanz, S., Ruiz, C. and Aldás, J. (2010) Why Some Internet Users Don't Buy Air Tickets Online. In: Gretzel, U., Law, R. and Fuchs, M., Eds., Information and Communication Technologies in Tourism, Springer, Vienna, 209-221. https://doi.org/10.1007/978-3-211-99407-8_18

[22] Koufaris, M. and Hampton-Sosa, W. (2004) The Development of Initial Trust in an Online Company by New Customers. Information \& Management, 41, 377-397. https://doi.org/10.1016/j.im.2003.08.004

[23] Morosan, C. and Jeong, M. (2008) Users' Perceptions of Two Types of Hotel Reservation Web Sites. International Journal of Hospitality Management, 27, 284-292. https://doi.org/10.1016/j.ijhm.2007.07.023

[24] Ayo, C.K., Adewoye, J.O. and Oni, A.A. (2011) Business-to-Consumer E-Commerce in Nigeria: Prospects and Challenges. African Journal of Business Management, 5, 5109-5117.

[25] Ajzen, I. (1991) The Theory of Planned Behavior. Organizational Behavior and Human Decision Processes, 50, 179-211. https://doi.org/10.1016/0749-5978(91)90020-T

[26] Athiyama, A. (2002) Internet Users' Intention to Purchase Air Travel Online: An Empirical Investigation. Marketing Intelligence \& Planning, 20, 234-242. https://doi.org/10.1108/02634500210431630

[27] Harkwick, J. and Barki, H. (1994) Explaining the Role of User Participation in Information System Use. Management Science, 40, 429-548. https://doi.org/10.1287/mnsc.40.4.440

[28] Chiou, J.S. (1998) The Effects of Attitude, Subjective Norm, and Perceived Behavioral Control on Consumers' Purchase Intentions: The Moderating Effects of Product Knowledge and Attention to Social Comparison Information. Proc. Natl. Sci. Counc., 9, 298-308.

[29] Park, S.Y. (2009) An Analysis of the Technology Acceptance Model in Understanding University Students Behavioral Intention to Use E-Learning. Educational Technology and Society, 12, 150-162.

[30] Burke, R.R. (2002) Technology and the Customer Interface: What Consumers Want in the Physical and Virtual Store. Journal of the Academy of Marketing Science, 30, Article No. 411. https://doi.org/10.1177/009207002236914

[31] Bhatnagar, A. and Ghose, S. (2004) Online Information Search Termination Patterns across Product Categories and Consumer Demographics. Journal of Retailing, 80, 221-228. https://doi.org/10.1016/j.jretai.2003.10.001 
[32] Mutengezanwa, M. and Mauchi F.N. (2013) Socio-Demographic Factors Influencing Adoption of Internet Banking in Zimbabwe. Journal of Sustainable Development in Africa, 15, 145-154.

[33] Padachi, K., Rojid, S. and Seetanah, B. (2008) Investigating into the Factors that Influence the Adoption of Internet Banking in Mauritius. Journal of Internet Business, 5, 99-116.

[34] Marumbwa, J. (2014) Exploring the Moderating Effects of Socio-Demographic Variables on Consumer Acceptance and Use of Mobile Money Transfer Services (MMTs) in Southern Zimbabwe. American Journal of Industrial and Business Management, 4, 71-79. https://doi.org/10.4236/ajibm.2014.42011

[35] Bagozzi, P.R. and Yi, Y. (2012) Specification, Evaluation, and Interpretation of Structural Equation Models. Journal of Academy of Marketing Science, 40, 8-34. https://doi.org/10.1007/s11747-011-0278-x

[36] Field, A. (2009) Discovering Statistics Using SPSS. 3rd Edition, SAGE Publications Inc., Thousand Oaks, California.

[37] Pallant, J. (2007) SPSS Survival Manual, a Step by Step Guide to Data Analysis Using SPSS for Windows. 3rd Edition, McGraw-Hill House, New York, 204. 